\title{
STRUCTURAL EQUATION MODELLING IN THE RESEARCH OF ENTREPRENEURIAL ORIENTATION: A SYSTEMATIC LITERATURE REVIEW
}

\author{
Vojtech Hruby
}

\begin{abstract}
Objective: To systematically review recent research of the entrepreneurial orientation utilising structural equation models. In particular, to review trends in number of research papers on these subjects, assess the methods used, number and type of the entrepreneurial orientation's dimensions and measures used.

Method: Web of Science database was first searched separately for the terms 'entrepreneurial orientation' and 'structural equation modelling' between 2011 and 2020 to look for trends in number of articles, countries where the research had been conducted and categories it was assigned to. In the second phase the Web of Science was searched for the combination of the two terms between 2019 and 2020 in title, abstract, key words, and key words plus. Exclusion and inclusion criteria were applied and data from selected articles was extracted using an extraction form and statistically analysed.
\end{abstract}

Results: The number of articles on both the entrepreneurial orientation and the structural equation modelling has been growing and the growth has accelerated in the last three years. 20 (39\%) articles were selected out of 51 hits resulting from the combined search. Research had taken place in 14 countries of which 5 amounted to $55 \%$ of all studies. $89 \%$ of studies were classified in at least one of the three Web of Science categories: business, management, economics. Average sample size was 278 companies and the most frequently used method was PLS-SEM. 85\% articles proposed recommendations for future research. The entrepreneurial orientation had mostly been measured with (Covin \& Slevin, 1989) measure (46\%) and 3 dimensions had been used in $90 \%$ of studies.

Conclusions: the theoretical concept of Entrepreneurial Orientation has been gaining popularity and structural equation modelling has been frequently used to analyse various correlations. PLS-SEM is the most frequently used method as well as the selection of 3 dimensions measured by the original (Covin \& Slevin, 1989) measure.

Keywords: Autonomy, Competitive Aggressiveness, Innovativeness, Partial Least Square, Proactiveness, Risk-taking

\section{INTRODUCTION}

The entrepreneurship is often considered to be the fundamental driving force of firms' productivity and growth. (Schumpeter, 2013) saw entrepreneurs as individuals striving to create new combinations, i.e., introduce new products and practically linked entrepreneurship with innovation. These two terms are frequently spelled out by governments world over seeking to reinvigorate the growth of economies as well as firms' owners and managers looking to fulfil noble visions or to simply hit the tough budget numbers. The key concept of the entrepreneurship from the perspective of the social science research is the entrepreneurial orientation. (Rauch et al., 2009) who studied the relationship between the entrepreneurial 
orientation and firms' performance concluded that the entrepreneurial orientation represents a perspective research field for building a relevant understanding of the entrepreneurship.

The utilisation of the structural equation modelling method in the social science research has indeed taken off during last 30 years. Its popularity may stem from the fact that a number of key concepts is not directly observable. The structural equation modelling combines latent variables representing a theoretical concept such as the entrepreneurial orientation and measured data (indicators, manifested variables) that is used as an input for the statistical analysis resulting in the proof of relations among latent variables (Williams et al., 2009). The author of this review set out to review the use of the entrepreneurial orientation and the structural equation modelling in the recent research individually and together. The main focus of this review was gaining a better understanding of methods used, number and type of the entrepreneurial orientation's dimensions and measures most often adopted in the research.

\section{THEORETICAL BACKGROUND / LITERATURE REVIEW}

\subsection{The entrepreneurial orientation}

The entrepreneurial orientation construct was first formulated by (Miller, 1983), who described an entrepreneurial organization as one that engages in product innovations, somewhat risky behaviour and is pro-active in relation to its competitors. (Lumpkin \& Dess, 1996) developed the theory further and added two more dimensions: competitive aggressiveness and autonomy. They argued that an enterprise in order to be successful needs its leaders and creative individuals be able to act independently, without any bureaucratic constraints. Competitive aggressiveness expresses how a company responds to risks. Contrary to (Miller, 1983), (Lumpkin \& Dess, 1996) emphasized that all the dimensions can vary independently in a given situation and can be defined as follows:

Autonomy is an expression of a free spirit, which is essential for all new. It is an independent action of an individual or a team aimed at enforcing the realization of an entrepreneurial concept or vision (Lumpkin \& Dess, 1996). Innovativeness is a willingness to introduce new concepts through experimentation and creative process focused on the development of new products, services, and processes. Risk taking was described as the decision making and realization without the knowledge of probable outcomes when some steps may include a significant resource allocation. Proactiveness is a forward looking perspective typical for a market leader who takes hold of opportunities expecting future demand. Competitive aggressiveness is an intensive effort to overcome the competition (Lumpkin \& Dess, 1996).

\subsection{The structural equation modelling}

The method allows researchers to model variables, that cannot be measured directly and at the same time to calculate measurement errors for variables, which can be measured. SEM evaluates two types of models: a) measurement model (outer model), which expresses the dependence between latent variables and their indicators, b) structural model (inner model), which expresses relations among latent variables. These relations reflect hypothesis based on theoretical assumptions (Mora, 2012). SEM provides a researcher with the option to: a) model relations among predictors (independent variables) and criterions (dependent variables), b) take into consideration latent variables, measured by indicators (measure variables), c) model measurement errors for measured variables and d) statistically test theoretical assumptions against empirical data. The holistic analysis, which SEM is capable of, is feasible with two statistical techniques: a) covariance-based SEM, b) variance-based SEM - PLS (Roldán \& Sánchez-Franco, 2012). PLS method was developed by Herman Wold with the aim of reflecting 
on theoretical and empirical conditions common in behavioural social sciences. The basic PLS algorithm runs in two phases: a) during the first phase the score of a latent variable is iteratively estimated, b) in the second phase final estimations are calculated (Hair et al., 2011). Since its creation in 1973 by Karl Jöreskog the covariance based structural equation modelling method has kindled lively interest among researchers. It estimates maximum probability with the goal of reproducing the covariance matrix (i.e., minimizing the difference between the observed and estimated covariance matrix) without focusing on the explained variance. In other words, with CB-SEM method R2 is a by-product of the main statistical goal of achieving a good fit of the model (Hair et al., 2011).

\section{METHODOLOGY}

\subsection{Data sources and search methods}

Three consecutive searches were conducted in the Web of Science in February and March 2021. The Web of Science was first searched for the term 'entrepreneurial orientation' and then independently for the words 'structural equation modelling' in the title or abstract or author key words or key words plus. The Web of Science offers an option to search for all four terms using a single search term 'Title', which was used in this review. The above defined search strategy was similar to that used by (Lyon, 2000). Below is the detailed description of the author's approach:

\#1 TOPIC: ("entrepreneurial orientation") AND LANGUAGE: (English) AND DOCUMENT TYPES: (Article) Indexes=SCI-EXPANDED, SSCI, A\&HCI, CPCI-S, CPCISSH, ESCI, CCR-EXPANDED, IC Timespan=2011-2020

\#2 TOPIC: ("structural equation modelling") AND LANGUAGE: (English) AND DOCUMENT TYPES: (Article) Indexes=SCI-EXPANDED, SSCI, A\&HCI, CPCI-S, CPCISSH, ESCI, CCR-EXPANDED, IC Timespan=2011-2020

The third search combined the previous two but focused on a shorter period of time:

\#3 \#2 AND \#1 Indexes=SCI-EXPANDED, SSCI, A\&HCI, CPCI-S, CPCI-SSH, ESCI, CCR-EXPANDED, IC Timespan=2019-2020

\subsection{Inclusion and exclusion criteria}

Only articles published in English language in refereed journals indexed in the Web of Science were included. The publication period of 10 years (between 2011 and 2020) for the search \#1 and \#2 was selected. Author estimated this period would be long enough for any trends in the number of published articles to be noticed. This would then help to draw conclusions about these terms' popularity and impact on contemporary research endeavours worldwide.

For the search \#3 the following additional inclusion criteria were added: i) article must contain a structural model drawing, i.e. a simple use of structural equation modelling method itself was not enough and a graphical expression of dependencies among theoretical constructs must have been included; ii) clear data analysis and iii) conclusions derived from the findings must be presented; iv) only articles with full text available were considered.

Similar to (Arain et al., 2010) the author decided to exclude review papers as they survey and summarise previously published studies, rather than reporting new facts and analysis (Saunders et al., 2015). 


\subsection{Selection and evaluation}

All articles returned by the search \#1 and \#2 were included. The title, abstract, author key words and Web of Science key words plus in the search \#3 were screened by the author for possible inclusion. Full texts were downloaded for the articles identified as possibly satisfying the inclusion criteria and evaluated for selection. The screening process was repeated on a $10 \%$ random sample of selected papers to validate the screening process (Chan et al., 2017). The screening process was also repeated on all papers containing one of the search terms only in the Web of Science category key words plus and not in title, abstract and author key words. Key word plus proved to be an unreliable field for inclusion suitability evaluation. E.g., articles with the search term 'Entrepreneurial orientation' only in the field key word plus and not in other search fields mostly did not research this construct at all and were only loosely connected to the subject.

\subsection{Data extraction}

Author of this review extracted data from all studies selected for inclusion by breaking down each study into its constituent parts and recoding recording the key points using data extraction form and applying rules on what to extract (Saunders et al., 2015) (see 'data extracted' column in Tab. 1). Data were recorded in a MS Excel spreadsheet.

Tab. 1 - Data Extraction Form. Source: adapted from (Chan 2017)

\begin{tabular}{|l|l|l|}
\hline No. & Items & $\begin{array}{l}\text { Data } \\
\text { extracted }\end{array}$ \\
\hline 1 & Name of first author & text \\
\hline 2 & Publication year & date \\
\hline 3 & Journal & text \\
\hline 4 & Title & text \\
\hline 5 & Country in which research was done & text \\
\hline 6 & Category & text \\
\hline 7 & Primary objective/research question & text \\
\hline 8 & Method used to address primary objective/research question & text \\
\hline 9 & Research sample size & number \\
\hline 10 & Term "entrepreneurial orientation" used in the title & yes/no \\
\hline 11 & Term "structural equation modelling used in the title & yes/no \\
\hline 12 & Entrepreneurial orientation dimensions number & number \\
\hline 13 & Entrepreneurial orientation dimensions type & text \\
\hline 14 & EO measure & text \\
\hline 15 & Summary findings & text \\
\hline 16 & Recommendations for future research & yes/no \\
\hline
\end{tabular}

Information extracted for items $1-6$ renders basic description of the selected articles. Primary objective/research question, unless explicitly specified by the author, was defined as the first 
objective mentioned in the abstract or elsewhere in the main text. Summary findings, unless summarised in the abstract, were extracted as the first finding from the summary section.

The final version of the full list of data extracted is included in Appendix 1.

\section{RESULTS}

The search \#1 of the Web of Science for the term "entrepreneurial orientation" returned 2104 articles published between 1.1.2011 and 31.12.2020 with the term appearing either in the title, abstract, key words, or key words plus. Second search \#2 with the otherwise same set-up for the term "structural equation modelling" resulted in an identification of 9663 papers. The combination of the above searches using Boolean operator AND (\#1 AND \#2) lead to an identification of 51 articles published between 1.1.2019 and 31.12.2020. One duplicate record was removed, and 50 full-text articles were downloaded and assessed for eligibility. 30 articles were then excluded for the following reasons: i) 25 papers did not research the term entrepreneurial orientation and the only reference to it was in the Web of Science field 'key words plus', ii) 3 articles contained no information about how the entrepreneurial orientation was measured and what type and number of the construct's dimensions were used, iii) 1 article did not use any structural model to visualise contingencies among theoretical constructs, iv) 1 article proposed new dimensions of the entrepreneurial orientation without any reference to published research. Figure 1 shows the flow diagram of the identification process for the sample of 20 studies included in this review. The full list of studies is included in the review in Tab. 2, with citations included in the final list of citations. 


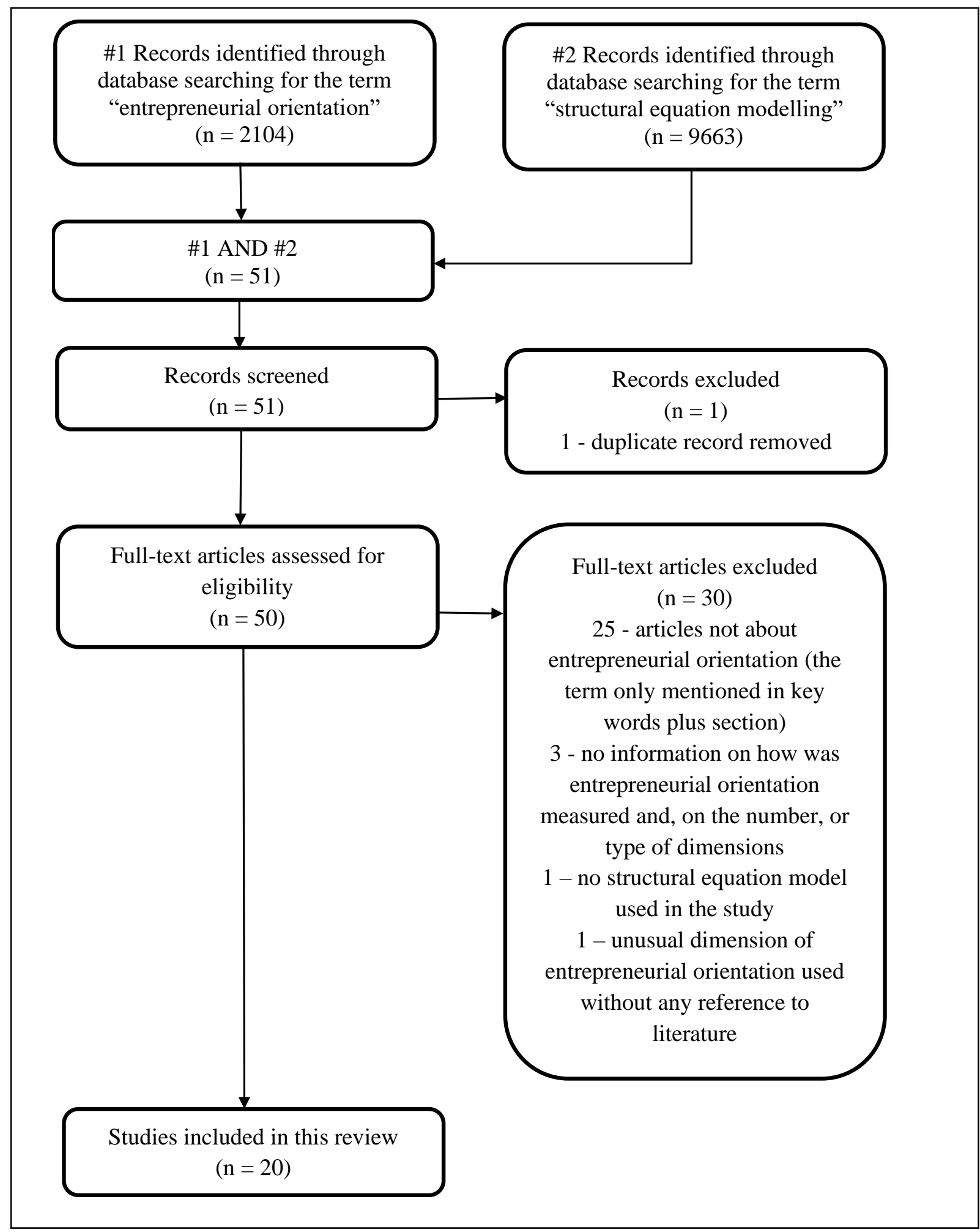

Fig. 1 - Flow diagram of the identification process for the sample of 20 articles included in this review. Source: own research 
Tab. 2 - Studies included in this review. Source: own research

\begin{tabular}{|c|c|c|c|}
\hline Author & Year & Journal & Title \\
\hline Al-Dhaafri & 2020 & $\begin{array}{l}\text { Benchmarking - } \\
\text { An International } \\
\text { Journal }\end{array}$ & $\begin{array}{l}\text { Impact of total quality management, organizational } \\
\text { excellence and entrepreneurial orientation on } \\
\text { organizational performance: empirical evidence } \\
\text { from the public sector in UAE }\end{array}$ \\
\hline Ali & 2020 & $\begin{array}{l}\text { Benchmarking - } \\
\text { An International } \\
\text { Journal }\end{array}$ & $\begin{array}{l}\text { Effect of entrepreneurial orientation, market } \\
\text { orientation and total quality management on } \\
\text { performance. Evidence from Saudi SMEs }\end{array}$ \\
\hline Alshanti & 2019 & $\begin{array}{lr}\text { Journal of } \\
\text { Innovation and } \\
\text { Knowledge }\end{array}$ & $\begin{array}{l}\text { Market-sensing capability, knowledge creation and } \\
\text { innovation: The moderating role of entrepreneurial } \\
\text { orientation. }\end{array}$ \\
\hline Aslam & 2020 & $\begin{array}{l}\text { Supply chain } \\
\text { management - an } \\
\text { international } \\
\text { journal }\end{array}$ & $\begin{array}{l}\text { Determining the antecedents of dynamic supply } \\
\text { chain capabilities }\end{array}$ \\
\hline Bhatti & 2020 & $\begin{array}{l}\text { Entrepreneurial } \\
\text { Business and } \\
\text { Economics } \\
\text { Review }\end{array}$ & $\begin{array}{l}\text { Organizational capabilities mediate between } \\
\text { organizational culture, entrepreneurial orientation, } \\
\text { and organizational performance of SMEs in } \\
\text { Pakistan }\end{array}$ \\
\hline Cannavale & 2019 & $\begin{array}{l}\text { The Journal of } \\
\text { Entrepreneurship }\end{array}$ & $\begin{array}{l}\text { Entrepreneurial Orientations and Performance: A } \\
\text { Problematic Explanatory Approach in the Iranian } \\
\text { Knowledge-Based Industry }\end{array}$ \\
\hline Cheah & 2019 & $\begin{array}{l}\text { Journal of Cleaner } \\
\text { Production }\end{array}$ & $\begin{array}{l}\text { Internal oriented resources and social enterprises' } \\
\text { performance: How can social enterprises help } \\
\text { themselves before helping others? }\end{array}$ \\
\hline Eniola & 2020 & $\begin{array}{l}\text { Small Enterprise } \\
\text { Research }\end{array}$ & $\begin{array}{l}\text { Entrepreneurial self-efficacy and orientation for } \\
\text { SME development }\end{array}$ \\
\hline Ferreira & 2019 & $\begin{array}{l}\text { International } \\
\text { Journal } \\
\text { Innovation } \\
\text { Science }\end{array}$ & $\begin{array}{l}\text { Dynamic capabilities, innovation and branding } \\
\text { capabilities and their impact on competitive } \\
\text { advantage } \\
\text { and SME's performance in Portugal: the } \\
\text { moderating effects of entrepreneurial orientation }\end{array}$ \\
\hline $\begin{array}{l}\text { Hernandez- } \\
\text { Perlinez }\end{array}$ & 2019 & $\begin{array}{l}\text { Economic } \\
\text { Research } \\
\text { Ekonomska } \\
\text { Istrazivanja } \\
\end{array}$ & $\begin{array}{l}\text { Innovativeness as a determinant of entrepreneurial } \\
\text { orientation: analysis of the hotel sector }\end{array}$ \\
\hline $\begin{array}{l}\text { Hernandez- } \\
\text { Perlinez }\end{array}$ & 2019 & $\begin{array}{l}\text { Economic } \\
\text { Research } \\
\text { Ekonomska } \\
\text { Istrazivanja }\end{array}$ & $\begin{array}{l}\text { Socioemotional wealth, entrepreneurial orientation } \\
\text { and international performance of family firms }\end{array}$ \\
\hline
\end{tabular}




\begin{tabular}{|c|c|c|c|}
\hline Irun & 2020 & $\begin{array}{l}\text { Journal of } \\
\text { Business Research }\end{array}$ & $\begin{array}{l}\text { Network market orientation as a relational } \\
\text { governance mechanism to public-private } \\
\text { partnerships }\end{array}$ \\
\hline Isichei & 2020 & $\begin{array}{l}\text { International } \\
\text { Journal of } \\
\text { Emerging Markets }\end{array}$ & $\begin{array}{l}\text { Entrepreneurial orientation and performance in } \\
\text { SMEs. The mediating role of structural } \\
\text { infrastructure capability }\end{array}$ \\
\hline Khan & 2019 & $\begin{array}{l}\text { Human Systems } \\
\text { Management }\end{array}$ & $\begin{array}{l}\text { Entrepreneurial orientation, intellectual capital, IT } \\
\text { capability, and performance }\end{array}$ \\
\hline Kim & 2019 & $\begin{array}{l}\text { Industry } \\
\text { Innovation }\end{array}$ & $\begin{array}{l}\text { What facilitates external knowledge utilization in } \\
\text { SMEs? - An optimal configuration between } \\
\text { openness intensity and organizational moderators }\end{array}$ \\
\hline Kiyabo & 2019 & $\begin{array}{l}\text { Journal of Global } \\
\text { Entrepreneurship } \\
\text { Research }\end{array}$ & $\begin{array}{l}\text { Strategic entrepreneurship, competitive advantage, } \\
\text { and SMEs' performance in the welding industry in } \\
\text { Tanzania }\end{array}$ \\
\hline Martins & 2019 & $\begin{array}{l}\text { European } \\
\text { Business Review }\end{array}$ & $\begin{array}{l}\text { The effects of market and entrepreneurial } \\
\text { orientation on the ambidexterity of multinational } \\
\text { companies' subsidiaries }\end{array}$ \\
\hline Seet & 2020 & $\begin{array}{l}\text { International } \\
\text { Journal } \\
\text { Manpower }\end{array}$ & $\begin{array}{l}\text { Understanding early-stage firm performance: the } \\
\text { explanatory role of individual and firm level } \\
\text { factors }\end{array}$ \\
\hline Valos & 2019 & $\begin{array}{l}\text { Journal } \\
\text { Strategic } \\
\text { Marketing }\end{array}$ & $\begin{array}{l}\text { How do alternative strategic orientations influence } \\
\text { social media performance? }\end{array}$ \\
\hline Veselinovic & 2020 & $\begin{array}{l}\text { Total Quality } \\
\text { Management \& } \\
\text { Business } \\
\text { Excellence }\end{array}$ & $\begin{array}{l}\text { The interplay of entrepreneurial orientation, total } \\
\text { quality management, and financial performance }\end{array}$ \\
\hline
\end{tabular}

\subsection{EO and SEM publishing trends}

The number of published articles on the subject of the entrepreneurial orientation has been growing steadily since 2011 , when the lowest number of papers was published -67 (3.18\% of the total of 2104 articles). The maximum number was recorded for the last year of the selected period $-525(24.95 \%)$. The average number in a year was 210 articles and median was 183 . There was only one occasion of no growth in the number of articles year on year (2016/2017), when the number remained 224. The trend is reported in the Figure 2. 


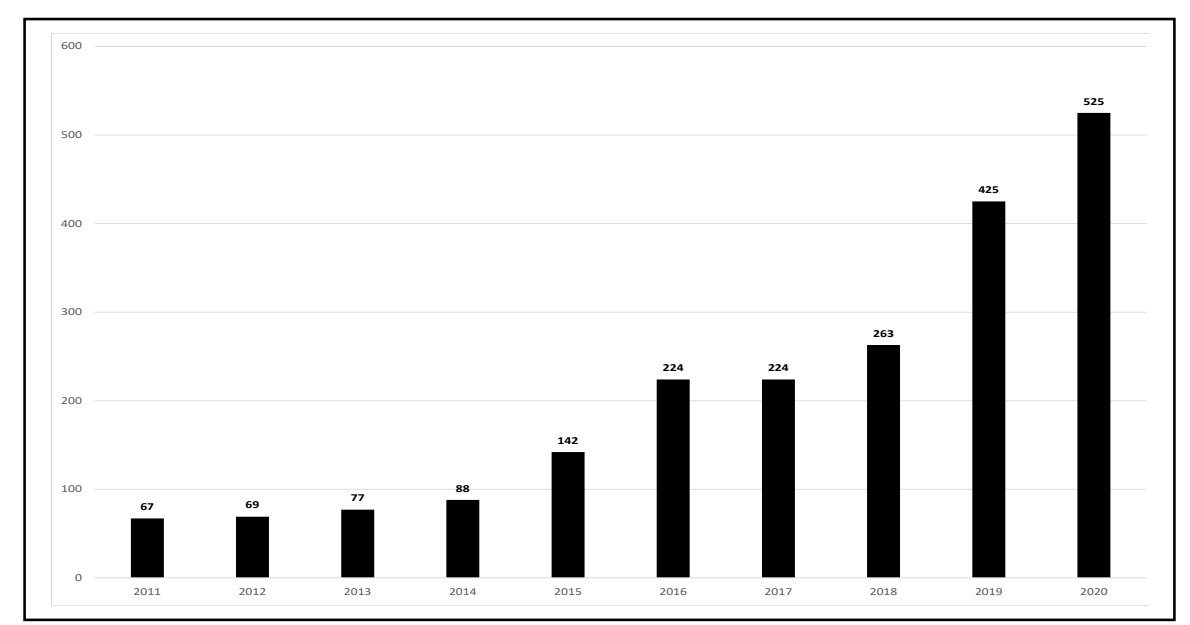

Fig. 2 - Number of published articles on the Entrepreneurial Orientation. Source: own research

Similar trend was unveiled for the frequency, with which the articles utilising the structural equation modelling had been published with the total number over the period of ten years between 2011 and 2020 of 9663 . Minimum of 311 in the first year and maximum of 2245 in 2020. Average number of articles in a year was 966 and median value was 844. In 2014 the number of articles decreased from 412 in 2013 to 411 . Since 2017 the number of publications has been accelerating as is visualised in Figure 3.

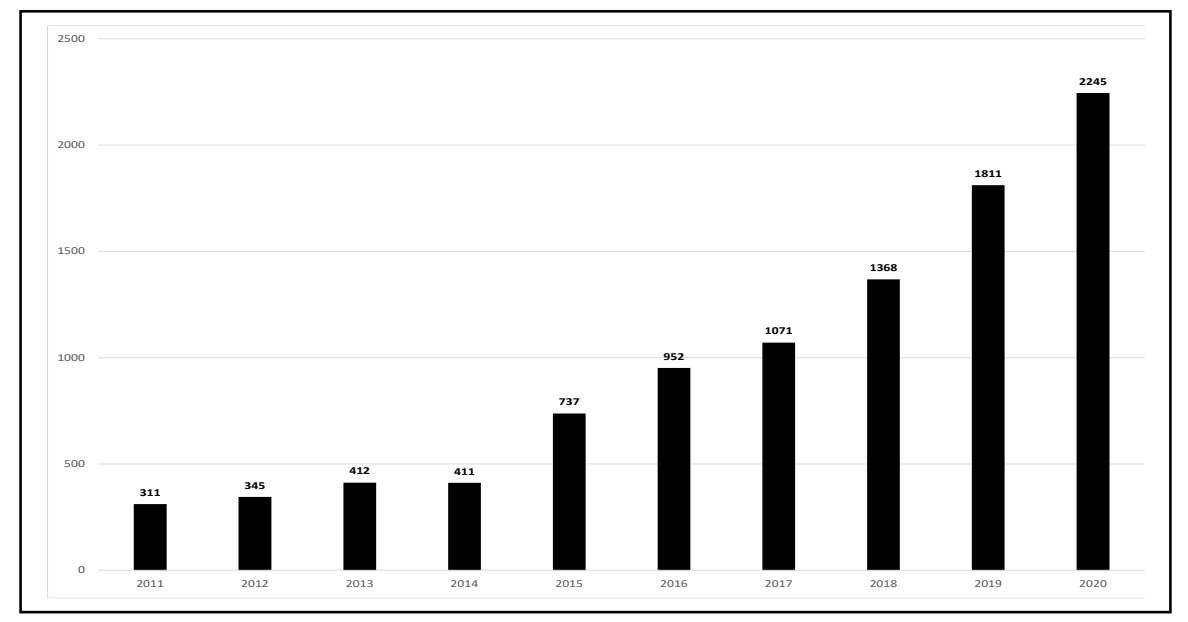

Fig. 3 - Number of published articles utilising the structural equation modelling. Source: own research

\subsection{Characteristics of the research sample}

Slightly more prolific proved to be the year 2019 with 11 (55\%) published articles in comparison with $9(45 \%)$ in 2020. Research discussed in $3(15 \%)$ articles took place in Pakistan. Australia, Nigeria, Spain and United Arab Emirates were the place of research of $2(10 \%)$ studies each. There were 9 other countries where $1(5 \%)$ study originated. The most popular Web of Science categories under which the research articles were listed were 'Business' and 'Management' with $9(35 \%)$ papers. 6 articles were listed in more than on category. Partial least square - Structural equation modelling (PLS-SEM) was the most frequently used research method utilised in 11 (52\%) articles. Average sample size was 278, minimum 102, maximum 477 with median value of 280 . The term 'entrepreneurial orientation' appeared in the title of majority of studies $-12(60 \%)$, while 'structural equation modelling' was only once used in the title $1(5 \%)$. Authors of selected articles included their recommendations for the future research 
on $17(85 \%)$ occasions. Characteristics of the articles selected for this review are summarised in Tab. 3.

Tab. 3 - Characteristic of studies included in this review. Source: own research

\begin{tabular}{|c|c|}
\hline Characteristics & $\begin{array}{l}\text { Number of articles } \\
(\%)\end{array}$ \\
\hline \multicolumn{2}{|l|}{ Publication year } \\
\hline 2019 & $11(55)$ \\
\hline 2020 & $9(45)$ \\
\hline \multicolumn{2}{|l|}{ Country } \\
\hline Pakistan & $3(15)$ \\
\hline Australia & $2(10)$ \\
\hline Nigeria & $2(10)$ \\
\hline Spain & $2(10)$ \\
\hline United Arab Emirates & $2(10)$ \\
\hline Bosnia and Herzegovina & $1(5)$ \\
\hline Brazil & $1(5)$ \\
\hline China & $1(5)$ \\
\hline Iran & $1(5)$ \\
\hline Jordan & $1(5)$ \\
\hline Korea & $1(5)$ \\
\hline Malaysia, Singapore & $1(5)$ \\
\hline Portugal & $1(5)$ \\
\hline Tanzania & $1(5)$ \\
\hline \multicolumn{2}{|l|}{ Web of Science Category } \\
\hline Business & $9(35)$ \\
\hline Management & $9(35)$ \\
\hline Economics & $5(19)$ \\
\hline $\begin{array}{l}\text { Green Sustainable Science } \\
\text { Technology }\end{array}$ & $1(4)$ \\
\hline Environmental Sciences & $1(4)$ \\
\hline Industrial Relations Labor & $1(4)$ \\
\hline \multicolumn{2}{|l|}{ Method } \\
\hline PLS-SEM & $11(52)$ \\
\hline SEM & $7(32)$ \\
\hline CB-SEM & $1(5)$ \\
\hline
\end{tabular}




\begin{tabular}{|l|l|}
\hline CFA & $1(5)$ \\
\hline fsQCA & $1(5)$ \\
\hline Sample & \multicolumn{1}{|l|}{278} \\
\hline Avg. sample size & 102 \\
\hline Min. sample size & 477 \\
\hline Max. sample size & 280 \\
\hline Median sample size & \multicolumn{2}{|l|}{} \\
\hline EO used in the title & $12(60)$ \\
\hline Yes & $8(40)$ \\
\hline No & \multicolumn{2}{|l|}{} \\
\hline SEM used in the title & $1(5)$ \\
\hline Yes & $19(95)$ \\
\hline No & \multicolumn{2}{|l|}{} \\
\hline Recommendations & $17(85)$ \\
\hline Yes & $3(15)$ \\
\hline No &
\end{tabular}

\subsection{Entrepreneurial orientation characteristics}

Authors of the selected group of studies quite overwhelmingly favoured the (Miller, 1983) approach to studying the entrepreneurial orientation expressed only by 3 dimensions - 18 (90\%) papers. $2(10 \%)$ articles included all 5 dimensions of the entrepreneurial orientation as defined by (Lumpkin \& Dess, 1996). Interestingly, only Proactiveness and Risk-taking were used in all $20(100 \%)$ studies. Innovativeness, which was one of the 3 original dimensions in (Miller, 1983) was only used 19 (95\%) times, and one article replaced it with Autonomy, which in total was utilised $3(15 \%)$ times. The least studied dimension $2(10 \%)$ was found to be competitive aggressiveness.

11 different measures of the entrepreneurial orientation were used in the articles selected for this review to measure the concept. The most frequently adopted measure was the one introduced by (Covin \& Slevin, 1989), which was used in 11 (46\%) studies. (Miller, 1983) was cited $4(17 \%)$ times. 9 other measures were referred to, all of them only once (4\%). The findings are summarised in Tab. 4. Author of this review did not investigate if those less known measures were original or adopted from one of the better known ones.

Tab. 4 -Characteristic of the entrepreneurial orientation in this review. Source: own research

\begin{tabular}{|l|l|}
\hline Characteristics & $\begin{array}{l}\text { Number of articles } \\
(\%)\end{array}$ \\
\hline EO dimensions number \\
\hline 3 & $18(90)$ \\
\hline 5 & $2(10)$ \\
\hline EO dimensions used \\
\hline
\end{tabular}




\begin{tabular}{|l|l|}
\hline Proactiveness & $20(100)$ \\
\hline Risk-taking & $20(100)$ \\
\hline Innovativeness & $19(95)$ \\
\hline Autonomy & $3(15)$ \\
\hline $\begin{array}{l}\text { Competitive } \\
\text { aggressiveness }\end{array}$ & $2(10)$ \\
\hline EO measure & $11(46)$ \\
\hline Covin, Slevin, 1989 & $4(17)$ \\
\hline Miller, 1983 & $1(4)$ \\
\hline Campos et al., 2012 & $1(4)$ \\
\hline Covin, Slevin, 1991 & $1(4)$ \\
\hline $\begin{array}{l}\text { Ebrahimi \& Mirbargkar, } \\
2017\end{array}$ & $1(4)$ \\
\hline $\begin{array}{l}\text { Fernandes and Santos, } \\
2008\end{array}$ & $1(4)$ \\
\hline Hughes and Morgan, 2007 & $1(4)$ \\
\hline Jantunen, 2005 & $1(4)$ \\
\hline Knight, 1997 & $1(4)$ \\
\hline Liu et al., 2014 & $1(4)$ \\
\hline Lumpkin \& Dess, 2001 & $1(4)$ \\
\hline
\end{tabular}

\section{DISCUSSION}

The results of this study indicate that there has been a lively interest within the social science research community in the theoretical construct of the entrepreneurial orientation and the analytical tool of the structural equation modelling. The author set out to look at trends in the frequency of publishing scientific articles where this construct and modelling method stood at the centre of research. A deep dive into a vast number of refereed articles indexed in the Web of Science aimed at gaining better understanding also of methods used, number and type of the entrepreneurial orientation's dimensions and measures most often adopted in the research. A few well know and widely cited papers in the 1980's, 1990's and 2000's (Miller, 1983), (Covin \& Slevin, 1989), (Lumpkin \& Dess, 1996), (Lyon, 2000) laid the foundations of research of the entrepreneurial orientation often utilising the structural equation modelling method. Some of the questions preceding this review were: is this field of research drying or gaining pace? Is the structural equation modelling often used in this field of social science research? Is any other method gaining prevalence? Has the scientific community preferred to look at the entrepreneurial orientation as a three or five-dimensional construct? What are the most cited measures?

The analysis confirms that the number of published articles researching the entrepreneurial orientation (2104) or utilising the structural equation modelling (9663) has been growing over the period of last ten years between 2011 and 2020 and the growth has been accelerating during last three years. The total of 20 articles on the entrepreneurial orientation utilising the structural 
equation modelling met the selection criteria. Most studies took place outside of Europe 16 $(80 \%)$. By far the most popular proved to be the partial least square - structural equation modelling $11(52 \%)$ and 3-dimension approach 18 (90\%). The questionnaire developed by (Covin \& Slevin, 1989) was the most frequently used measure.

The concept of entrepreneurship as a way of introducing new combinations to the market while undertaking risk (Schumpeter, 2013) has attracted new popularity with the ascent of the Internet. It's been often studied in the social sciences as the theoretical construct of the entrepreneurial orientation. This review has confirmed past studies (Lyon, 2000), (Farkas, 2016) in that the construct has been gaining popularity and the number of papers on the topic has been growing. It can be concluded that a lot of authors from various fields within the social science see it not only as an interesting research subject, but also as a legitimate way of studying the entrepreneurship from the science point of view in the context of many industries and different countries.

The structural equation modelling method has appeared more than four times more often in the research articles over the period of ten years than the entrepreneurial orientation. Some authors (Sarstedt et al., 2014) argue that this method in general and the partial least square - structural equation modelling method more specifically, is particularly useful in the social science research. A cohort of scholars (Ronkko \& Evermann, 2013) has voiced their concerns over the method's supposed advantages and has argued in favour of the covariance-based approach to the structural equation modelling (CB-SEM). This review uncovers the fact that a growing number of researches has been choosing the structural equation method as a tool for modelling dependencies and analysing their research problems. That's in line with (Henseler et al., 2014), who have not only been promoting the partial least square structural equation modelling, but have also insisted that no method is universally applicable and better than other methods and that the individual research context needs to be considered before selecting a suitable method.

While some of the previous research (Lumpkin \& Dess, 1996) has looked at the theoretical construct of the entrepreneurial orientation as a multidimensional one, consisting of 5 individual dimensions - innovativeness, risk-taking, pro-activeness, autonomy, competitive aggressiveness - this review has proved that at least over the period of last two years the overwhelming majority opted for the original approach of (Miller, 1983), who defined the construct as a three dimensional. In this review author's view, the reason behind this trend may be quite simple: it's arguably easier to measure three-dimensional construct than a five dimensional one. On top of that a well-known and reliable measure developed by (Covin \& Slevin, 1989) is freely available and multiple examples of its use can be found in the literature.

This review's strengths lie in the robust search and data extraction procedure that has built on the similar and repeatedly cited articles (Chan et al., 2017), (Arain et al., 2010). The fact that the selection criteria stipulated that the search terms must appear not only in the title or abstract, but also in the key words, increased the chance that relevant articles would be captured. The obvious limitation of this study is the use of only one database, the Web of Science, which is comprehensive but not complete and therefore relevant and eligible papers might have been missed.

\section{CONCLUSION}

This article aimed to systematically review recent research of the entrepreneurial orientation utilising structural equation models. Based on the search results, a well-designed data extraction procedure and a list of exclusion and inclusion criteria, it can be concluded that the popularity of the entrepreneurial orientation and the structural equation modelling expressed as a number of published articles, has been growing. The researchers most often look at the construct 
through the lens of three dimensions, measuring it with the (Covin \& Slevin, 1989) measure and utilising the partial least square - structural equation modelling.

To get a broader picture, practitioners should extend the search to other databases and look at a longer period of time. The scope of this review did not allow to analyse the structural equation models used in the selected papers. The way researchers model the relations among predictors (latent variables) and criterions (dependent variables) may prove to be an interesting are for future research. It can also analyse what indicators (measure variables) have been used to measure latent variables and how the research theoretical assumptions have been statistically tested.

\section{References}

Arain, M., Campbell, M., Cooper, C., \& Lancaster, G. (2010). What is a pilot or feasibility study? A review of current practice and editorial policy. BMC Medical Research Methodology, 10(1). doi: 10.1186/1471-2288-10-67

Covin, J., \& Slevin, D. (1989). The strategic management of small firms in hostile and benign environments. Strategic Management Journal, 1989(101), 75-87. doi: 10.1002/smj.4250100107

Farkas, G. (2016). The Effects of Strategic Orientations and Perceived Environment on Firm Performance. Journal of Competitiveness, 8(1), 55-65. doi: 10.7441/joc.2016.01.04

Hair, J., Ringle, C., \& Sarstedt, M. (2011). PLS-SEM: Indeed a Silver Bullet: Indeed a Silver Bullet. Journal of Marketing Theory and Practice, 19(2), 139-152. doi: 10.2753/MTP1069-6679190202

Henseler, J., Dijkstra, T., Sarstedt, M., Ringle, C., Diamantopoulos, A., Straub, D., Ketchen, D., Hair, J., Hult, G., \& Calantone, R. (2014). Common Beliefs and Reality About PLS: Comments on Ronkko and Evermann (2013). Organizational Research Methods, 17(2), 182-209. doi: 10.1177/1094428114526928

Chan, C., Leyrat, C., \& Eldridge, S. (2017). Quality of reporting of pilot and feasibility cluster randomised trials: a systematic review. BMJ Open, 7(11), 1-14. doi: 10.1136/bmjopen2017-016970

Lumpkin, G., \& Dess, G. (1996). CLARIFYING THE ENTREPRENEURIAL ORIENTATION CONSTRUCT AND LINKING IT TO PERFORMANCE. Academy of Management Review, 21(1), 135-172. doi: 10.5465/AMR.1996.9602161568

Lyon, D. (2000). Enhancing entrepreneurial orientation research: operationalizing and measuring a key strategic decision making process. Journal of Management, 26(5), 1055-1085. doi: 10.1016/S0149-2063(00)00068-4

Miller, D. (1983). The Correlates of Entrepreneurship in Three Types of Firms. Management Science, 29(7), 770-791. doi: 10.1287/mnsc.29.7.770

Mora, M. (2012). Research Methodologies, Innovations and Philosophies in Software Systems Engineering and Information Systems. IGI Global.

Rauch, A., Wiklund, J., Lumpkin, G., \& Frese, M. (2009). Entrepreneurial Orientation and Business Performance: An Assessment of Past Research and Suggestions for the Future. Entrepreneurship Theory and Practice, 33(3), 761-787. doi: 10.1111/j.15406520.2009.00308.x 
Roldán, J., \& Sánchez-Franco, M. (2012). Variance-Based Structural Equation Modeling. In M. Mora, O. Gelman, A. L. Steenkamp, \& M. Raisinghani (Eds.), Research Methodologies, Innovations and Philosophies in Software Systems Engineering and Information Systems (pp. 193-221). IGI Global. doi: 10.4018/978-1-4666-0179-6.ch010

Ronkko, M., \& Evermann, J. (2013). A Critical Examination of Common Beliefs About Partial Least Squares Path Modeling. Organizational Research Methods, 16(3), 425-448. doi: $10.1177 / 1094428112474693$

Sarstedt, M., Ringle, C., Henseler, J., \& Hair, J. (2014). On the Emancipation of PLS-SEM: A Commentary on Rigdon (2012). Long Range Planning, 47(3), 154-160. doi: 10.1016/j.lrp.2014.02.007

Saunders, M., Lewis, P., \& Thornhill, A. (2015). Research methods for business students. Pearson Education.

Schumpeter, J. (2013). Capitalism, Socialism and Democracy. Taylor \& Francis.

Williams, L., Vandenberg, R., \& Edwards, J. (2009). 12 Structural Equation Modeling in Management Research: A Guide for Improved Analysis. The Academy of Management Annals, 3(1), 543-604. doi: 10.1080/19416520903065683

\section{Contact information}

\section{Ing. Vojtěch Hrubý}

Brno University of Technology, Faculty of Business and Management

Kolejní 2906/4, Brno, 61200

E-mail: xphruby05@vutbr.cz

ORCID: 0000-0001-9165-5544

doi: 10.7441/dokbat.2021.19 